\title{
ANALISIS DAN PERANCANGAN APLIKASI CRM BERBASISKAN WEB PADA LEMBAGA PENDIDIKAN BAHASA
}

\author{
Lea Sulaiman Saputra \\ Computerized Accounting Department, School of Information Systems, Binus University \\ Jln. K.H. Syahdan No. 9, Palmerah, Jakarta Barat 11480 \\ lea_saputra@hotmail.com
}

\begin{abstract}
ABSTRAK
Tujuan studi ini adalah merancang sebuah aplikasi CRM berbasiskan web pada sebuah lembaga pendidikan bahasa untuk meningkatkan pelayanan kepada siswa. Diharapkan penggunaan aplikasi ini dapat membantu memberikan kemudahan bagi siswa selama maupun setelah proses pembelajaran. Metodologi dan pendekatan yang digunakan dalam artikel ini adalah analisis studi pustaka, wawancara, dan hasil survei, serta perancangan. Hasil yang diperoleh adalah bahwa perancangan aplikasi CRM ini dapat berjalan dengan baik. Aplikasi CRM ini dapat mendukung dan membantu calon siswa/siswa dalam hal program pembelajaran; membantu customer service lembaga pendidikan bahasa membina dan meningkatkan hubungan dengan calon siswa maupun siswa; serta dapat membantu promosi lembaga pendidikan bahasa tersebut.
\end{abstract}

Kata kunci: CRM, web, pelayanan, promosi

\begin{abstract}
The purpose of this paper is to design a web-based CRM applications in language education institutions to improve services to siswas. Expected use of these applications can help siswas in terms of providing ease of learning takes place during and after the learning process is completed. Methodology and approach used in this paper is analysis of literature study, interviews, survey results, and design. The results obtained is that the CRM application designed can be run well. The CRM application can support and assist both prospective siswas and siswas related to study programs, support the customer service of the involved language educational institution in developing relationships with both prospective members and members, and help promote the institution.
\end{abstract}

Keywords: CRM, web, services, promotion 


\section{PENDAHULUAN}

Dalam persaingan bisnis banyak hal yang bisa digunakan untuk memenangkan konsumen seperti harga, kualitas produk, servis dan lainnya. Untuk dapat bertahan dalam persaingan tersebut bukanlah hal yang mudah, apalagi memenangkan persaingan tersebut. Mengiklankan produk dan memperoleh konsumen bukanlah suatu jaminan, dengan ketatnya persaingan yang ada, sangatlah mungkin konsumen akan berpindah dari satu produsen ke produsen yang lain. Dengan adanya teknologi internet dan e-commerce, hal ini semakin mudah terjadi. Dengan banyaknya search engine di internet, seorang konsumen dapat dengan sangat mudah mencari produk-produk pembanding.

Untuk dapat tetap bertahan dalam dunia perdagangan tersebut, produsen harus menempuh berbagai cara sejauh tidak bertentangan dan atau melanggar hukum. Dari segi pandang konsumen, pada umumnya konsumen tentu lebih memilih suatu produk dengan harga yang lebih murah dibanding produk lain yang sejenis. Namun harga belum dapat dijadikan patokan, sebab seiring dengan berkembangnya teknologi produksi kini konsumen tidak hanya mempertimbangkan harga untuk membeli suatu produk tetapi juga sudah mempertimbangkan mutu produk yang dijual dan servis yang diberikan oleh penjual itu sendiri. Oleh karena itu dalam persaingan bisnis yang ada produsen tidak bisa hanya mengandalkan persaingan fisik seperti tempat yang bagus, luas dan sebagainya. Tetapi perlu diperhatikan juga kesetiaan pelanggan yang dapat diperoleh dengan berbagai cara, antara lain dengan memberikan kepuasan kepada pelanggan. Jika seorang pelanggan merasa mendapatkan value yang sesuai dengan harga yang ia bayar, pelanggan tersebut akan merasa puas.

Harga yang murah belum tentu menjadi jaminan pelanggan akan merasa memperoleh value yang sesuai dengan yang diinginkan. Pelanggan yang merasa puas lama kelamaan akan terpupuk loyalitasnya dengan sendirinya. Loyalitas atau kesetiaan pelanggan inilah yang bisa kita anggap kita memenangkan suatu persaingan bisnis. Dengan loyalitas yang tinggi, seorang pelanggan akan tidak mudah berpindah ke saingan lain, misalnya muncul produk saingan dengan harga lebih murah, atau produk baru sejenis.

Untuk memperoleh loyalitas pelanggan ini, dalam bisnis perlu menerapkan Electronic Customer Relationship Management (E-CRM), di mana saat ini bisnis lebih difokuskan pada pelanggan serta bagaimana membina hubungan yang lebih baik, yaitu tidak hanya dengan sekedar memberikan kepuasan pada pelanggan tapi bagaimana mendapatkan loyalitas dari pelanggan. Begitu pula dalam dunia pendidikan, E-CRM juga dapat dijadikan sebagai salah satu faktor pendorong agar konsumen dapat tertarik kepada tempat kursus yang ditawarkan yang disertai dengan adanya fasilitasfasilitas yang menunjang pelaksanaan pendidikan tersebut dengan memberikan berbagai kemudahan bagi siswanya. Oleh karena itu, lembaga pendidikan bahasa selalu berusaha memperbarui dan menambah fasilitas- fasilitas bagi siswanya agar tetap dapat bersaing dengan tempat- tempat kursus lainnya. Salah satunya melalui E-CRM, dengan harapan lembaga pendidikan bahasa dapat memperoleh konsumen baru, mempertahankan siswa yang sudah ada serta memberikan pelayanan guna kepuasan siswa lembaga pendidikan bahasa dalam proses pembelajaran di lembaga pendidikan bahasa ini.

Karena luasnya cakupan dalam dunia bisnis dan teknologi informasi, penelitian dibatasi pada: (1) analisis dan perancangan aplikasi CRM berbasiskan web yang berfokus pada pelayanan siswa lembaga pendidikan bahasa; (2) analisis dan Perancangan aplikasi CRM ini hanya ditujukan untuk penggunaan pada lembaga pendidikan bahasa; (3) analisis dan perancangan aplikasi CRM tidak membahas keuangan lembaga pendidikan bahasa; (4) analisis dan perancangan aplikasi CRM ini tidak membahas masalah keamanan. 
Adapun tujuan dari penelitian perancangan E- CRM yang ingin dicapai antara lain untuk memberikan gambaran informasi yang sebaiknya disajikan oleh lembaga pendidikan bahasa dalam memenuhi kebutuhan para pencari informasi khususnya siswa lembaga pendidikan bahasa.

Sedangkan manfaat yang dapat diperoleh antara lain: (1) meningkatkan loyalitas siswa lembaga pendidikan bahasa sehingga dapat mempertahankan hubungan dengan siswa yang sudah ada; (2) memperluas jangkauan penyampaian informasi kepada siswa lembaga pendidikan bahasa.

\section{METODE}

Metodologi yang digunakan dibagi menjadi dua bagian. Pertama adalah analisis. Dalam metode ini, penulis melakukan analisis terhadap hasil survei yang telah dikumpulkan, kemudian dilakukan identifikasi terhadap kebutuhan sistem dan identifikasi persyaratan sistem. Hasil analisis sitem akan digunakan sebagai masukkan bagi rancangan sistem yang akan diusulkan. Kedua adalah perancangan. Pada metode ini dilakukan permodelan sistem dengan cara: (1) pembuatan use case diagram; (2) pembuatan activity diagram; (3) pembuatan class diagram; (4) pembuatan spesifikasi database; (5) pembuatan rancangan layar.

\section{HASIL DAN PEMBAHASAN}

\section{Cara Kerja Internet}

Internet bekerja berdasarkan perpindahan data antar komputer dalam urutan jaringan dan internet membutuhkan beberapa hal untuk melakukan perpindahan tersebut seperti alamat tujuan dan perantara (Internet Service Provider) serta sebuah protokol untuk menjamin sampainya data pada tujuan.

Protokol ini memiliki dua bagian yaitu: (1) Transmission Control Protocol (TCP) - fungsinya untuk membagi-bagi informasi yang akan dikirim menjadi paket data yang kecil dan merakitnya kembali menjadi bentuk aslinya; (2) Internet Protocol (IP) - fungsinya untuk menjamin paket yang dikirim dapat mencapai tujuan dan standar IP membagi alamat menjadi seputuh digit dengan setiap kelompok digit memiliki referensi pengalamatan tersendiri.

Saat paket TCP/IP tiba di tempat tujuannya, komputer akan membuka alamat IP lalu menggunakan daftar pengiriman yang ada pada paket TCP untuk memeriksa adanya kerusakan paket yang terjadi selama pengiriman dan menyusun kembali paket-paket tersebut menjadi data seperti aslinya. Saat komputer penerima menemukan paket yang rusak, komputer tersebut akan meminta komputer pengirim untuk mengirim salinan yang baru dari paket yang rusak.

\section{Evolusi Usaha Pemasaran Internet}

Internet Market Effort secara tradisional mengikuti pola perkembangan yang sama dengan media lain. Meskipun setiap Internet Communication Effort berbeda namun pola evolusi komunikasi internet telah menjadi bukti yang membantu dalam merencanakan dan menciptakan upaya-upaya.

Penggunaan internet oleh perusahaan-perusahaan dan organisasi-organisasi lain pada umumnya menggunakan enam tingkatan pengembangan (Greenberg, 2002). Pertama, iklan. Pada 
tingkatan ini penggunaan World Wide Web (www) untuk menampilkan beberapa home page dan page link. Namun perusahaan pada umumnya membuat halaman web melebihi dari kebutuhan bisnis perusahaan itu sendiri. Kenyataannya memiliki home page pada www seperti meletakkan billboard di basement. Home page memiliki nilai bagi perusahaan tapi user tidak tahu guna upaya yang telah dilakukan dalam membuat home page tersebut. Ciri home page biasanya dihubungkan dengan informasi seperti gambar sebuah gedung perusahaan dan pesan dari perusahaan tersebut. Kedua, promosi. Kemudahan yang relatif dari pengembanan halaman web statis telah mengarah pada konversi secara ekstensif dari brosur dan materi-materi yang promosional dari aplikasi desktop publishing (format elektronik) ke $w w w$ yang elektronis.

Hal ini menyebabkan ledakan jumlah halaman pada sebuah situs web tanpa meningkatkan nilai dari usaha komunikasi kepada pengguna. Seringkali disebut brochureware, penambahan jumlah halaman-halaman ini di dalam situs perusahaan ditambahkan ke kesenangan pribadi daripengguna dan manajer tapi seperti pada level pertama, site ini tidak melakukan apa-apa untuk menciptakan keperluan bisnis tambahan, menciptakan pertukaran informasi yang memadai ataupun meningkatkan hubungan. Ketiga, interaksi. Pada fase ini penggunaan internet pertama kalinya digunakan untuk menyediakan nilai bagipelanggan dengan menawarkan pertukaran informasi yang bernilai.

Pengunjung situs web dapat menerima informasi mengenai semua yang mereka ingin ketahui dan bukan informasi mengenai perusahaan. Pengunjung dapat memperoleh informasi dari situs web perusahaan. Dengan menggunakan presentasi berbasis database, level interaksi ini memungkinkan untuk menyediakan informasi kepada pelanggan dan mereka mendapatkan informasi yang diinginkan tanpa kesulitan. Tingkatan interaktif ini memuaskan kebutuhan dan keinginan pelanggan serta menurunkan biaya dengan mengurangi permintaan pada layanan pelanggan. Keempat, transaksi. Pada level ini pelanggan dapat melakukan aksi dan menyelesaikan transaksi setelah pertukaran informasi di internet.

Calon pelanggan dapat merespon ke dan menerima penawaran online perusahaan pada media lain. Sebagai contoh sebuah billboard dapat berisi situs web untuk memberikan respon. Alamat situs web tersebut khusus ditujukan untuk penawaran produk dan pendapatan informasi kontak pelanggan untuk menyelesaikan transaksi secara online. Kelima, tranformasi. Pada level ini hubungan antara perusahaan dan pasarnya telah bergeser dari tradisional ke elektronik. Penggunaan internet telah dijadikan standar komunikasi perusahaan dengan konsumennya. Transformasi dapat memiliki efek merusak yang dapat mengakibatkan penyelarasan ulang dan restrukturisasi dari hubungan antara distribusi dan pasarnya. Dan keenam adalah komunitas. Level ini merupakan level yang paling tinggi dari perkembangan internet. Sekelompok orang dengan minal yang sama dikumpulkan bersama dengan keterlibatan emosi. Hubungan emosional ini dapat berupa komunikasi probadi pada sebuah subjek seperti masalah kesehatan. Komunitas merupakan sekelompok orang dengan minat yang sama pada sebuah topik atau masalah yang tidak perlu berkumpul secara langsung. Komunitas mendorong siswanya untuk berkomunikasi satu dengan yang lainnya dalam sebuah organisasi.

Dalam keenam tahap tersebut perusahaan dapat berada di antaranya ataupun pada tahap proses salahs atunya. Perusahaan pada tahap keenam dipandang telah berhasil menjalankan strategi internetnya dalam kegiatan keseharian perusahaan.

\section{Visi dan Misi}

Adapun visi lembaga pendidikan bahasa adalah "Menjadi pusat pembelajaran yang terbaik dan yang tersebar di Indonesia melalui berbagai program pendidikan dan sarana penunjangnya terutama pendidikan bahasa”. Sedangkan misi lembaga pendidikan bahasa adalah sebagai berikut: (1) menciptakan suasana belajar yang menyenangkan dan memenuhi kebutuhan intelektual, emosional dan spiritual; (2) menciptakan suatu struktur organisasi dinamis yang mendukung dan mempercepat 
kemungkinan partisipasi pengguna jasa dan mitra usaha dalam tatanan manajemen yang sehat dan professional; (3) meningkatkan kinerja karyawan dan sekaligus kinerja unit kegiatan; (4) mengadakan pengembangan organisasi dan sekaligus merancang sistem kerjanya secara efektif dan efisien; (5) memperlancar penyelesaian masalah penting dan mendesak yang berkaitan dengan adanya pengembangan usaha; (6) menciptakan rasa ketenangan bekerja melalui sistem imbal jasa yang memadai dan sistem pengembangan karir yang jelas.

\section{Strategi Harga}

Lembaga pendidikan bahasa menawarkan harga yang kompetitif dan relatif terjangkau oleh masyarakat. Dalam menentukan kenaikan harga yang biasanya dilakukan setiap dua tahun sekali terlebih dahulu dilakukan survei dan evaluasi untuk menentukan kelayakan kenaikan atau tidak. Harga yang ditawarkan tentu saja sesuai dengan ilmu yang akan diperoleh.

\section{Strategi Promosi}

Dalam promosi, lembaga pendidikan bahasa memakai strategi konvensional yakni penayangan iklan di media cetak maupun elektronik sebagai promosi yang bersifat above line dan kunjungan ke sekolah- sekolah sebagai promosi below the line. Untuk mengaktifkan kegiatan promosi dalam komunitas ini lembaga pendidikan bahasa juga mengadakan kerjasama organisasi dan mengikut sertakan siswa dalam berbagai perlombaan bahasa Inggris. Promosi berupa dari mulut ke mulut juga banyak membantu perkembangan lembaga pendidikan bahasa dari tahun ke tahun.

\section{Analisis Kuesioner}

Berikut 10 pertanyaan yang diajukan kepada responden (kepada siswa lembaga pendidikan) yang dibagikan secara acak:

1. Apakah Anda mengetahui informasi mengenai semua kursus- kursus yang tersedia di lembaga pendidikan bahasa?

2. Apakah Anda mengalami kesulitan dalam memperoleh informasi pada lembaga pendidikan bahasa?

3. Kesulitan apa yang sering Anda alami pada lembaga pendidikan bahasa? (jawaban boleh lebih dari satu).

4. Menurut Anda, apakah perlu adanya informasi berbasiskan komputer yang interaktif dan dapat memberikan informasi mengenai materi, sistem pengajaran, fasilitas dan lain- lain?

5. Informasi apa sajakah yang Anda butuhkan? (jawaban boleh lebih dari satu).

6. Menurut Anda, apakah perlu adanya online pendaftaran ? (jika jawaban = perlu, lanjutkan ke pertanyaan no 7. Jika jawaban $=$ Tidak Perlu, lanjutkan ke pertanyaan no 9 )

7. Seberapa sering Anda mengakses internet dalam sebulan?

8. Di mana anda sering mengakses internet?

9. Berapa kali Anda telah mengambil kursus di lembaga pendidikan bahasa ini?

10. Dari mana Anda mengetahui lembaga pendidikan bahasa?

Berdasarkan hasil kuesioner, dapat diketahui hal-hal sebagai berikut: Sebanyak 27 siswa atau 39.7\% responden mengetahui informasi mengenai semua kursus-kursus yang tersedia di lembaga pendidikan bahasa ini. Sementara 41 siswa atau 60.3\% responden tidak mengetahui. 23 siswa atau 33.8\% responden mengalami kesulitan dalam memperoleh informasi pada lembaga pendidikan bahasa ini. Sementara 45 siswa atau $66.2 \%$ responden tidak mengalaminya.

Ketika ditanya mengenai kesulitan yang sering Anda alami pada lembaga pendidikan bahasa (jawaban boleh lebih dari satu), 15 siswa menjawab membutuhkan waktu yang lama untuk 
mendapatkan informasi, 27 siswa menyatakan informasi yang ada kurang jelas, 10 siswa menjawab informasi tidak tersedia, 27 siswa menyatakan penempatan informasi yang tidak/kurang strategis, dan 8 siswa menjawab kesulitan lainnya. 66 siswa (97\%) menyatakan perlu adanya informasi berbasiskan komputer yang interaktif dan dapat memberikan informasi mengenai materi, sistem pengajaran, fasilitas dan lain- lain, sedangkan dua siswa (3\%) menyatakan tidak perlu.

Mengenai informasi yang dibutuhkan, 37 siswa memilih informasi kursus- kursus yang tersedia di lembaga pendidikan bahasa, 44 siswa memilih informasi event yang diselenggarakan seperti: pertandingan, beasiswa dan lain- lain, dan satu siswa meilih informasi lainnya. 65 siswa (95.5\%) menyatakan perlu adanya pendaftaran online, dan tiga siswa (4.5\%) menyatakan tidak perlu.

Mengenai frekuensi mengakses internet dalam sebulan, lima siswa (7.6 \%) mengakses internet 1-10 jam, 18 siswa (27.7\%) 11-20 jam, dan 42 siswa (67.7\%) bisa mengakses internet $>20$ jam. 29 siswa (44.6\%) menyatakan lebih sering mengakses internet di rumah, 14 siswa (21.5\%) di kampus/sekolah, enam siswa (9,2\%) di kantor, dan 16 siswa (24,7\%) di warnet. 46 siswa (67.6\%) baru 1 kali mengambil kursus di lembaga pendidikan bahasa ini, 17 siswa (25\%) sudah antara 1-5 kali, dan 5 siswa (7.4\%) sudah lebih dari 5 kali . 53 siswa (78\%) mengetahui lembaga pendidikan bahasa ini dari teman, tiga siswa (5\%) mengetahui dari majalah, satu siswa (1\%) mengetahui dari iklan, dan 11 siswa (16\%) mengetahui dari sumber lainnya.

\section{Identifikasi Masalah}

Dalam menjalankan operasinya sebagai lembaga pendidikan, lembaga pendidikan bahasa ini mengalami berbagai kendala yang menyebabkan tidak tercapainya kepuasan siswa-siswa pelatihan. Kendala yang muncul merupakan tantangan dan peluang bagi lembaga pendidikan bahasa. Dikatakan tantangan karena permasalahan yang dihadapi harus mampu diselesaikan. Namun bila tidak, permasalahan tersebut akan menghambat perkembangan lembaga pendidikan bahasa. Kendala tersebut juga bisa dikatakan peluang. Jika masalah tersebut dapat diselesaikan dengan baik dan memuaskan siswa-siswa yang mengikuti kursus di lembaga pendidikan bahasa, siswa-siswa akan semakin antusias akan pelayanan dan produk-produk yang ditawarkan lembaga pendidikan bahasa. Pada intinya, semua masalah yang terjadi harus segera diatasi dan keputusan yang diambil harus mencakup kepuasan baik calon siswa maupun siswa dan lembaga pendidikan bahasa itu sendiri.

Permasalahan yang ada pada lembaga pendidikan bahasa yang diteliti antara lain: (1) pelayanan yang belum maksimal - pelayanan yang diberikan oleh lembaga pendidikan bahasa sudah cukup baik dalam beberapa hal, namun masih terdapat kekurangan. Kekurangan tersebut antara lain dalam hal penanyaan jadwal dan nilai. Untuk menanyakan jadwal dan nilai, siswa yang mengambil kursus di lembaga pendidikan bahasa harus menelpon terlebih dahulu padahal telpon yang ada di lembaga pendidikan bahasa bersifat hunting sehingga siswa yang menelpon harus menunggu lama mengingat banyaknya jumlah siswa yang kursus di lembaga pendidikan bahasa ini; (2) pendaftaran yang dilakukan masih belum efektif dan efisien - saat ini lembaga pendidikan bahasa ini melakukan pendaftaran dengan cara calon siswa datang ke lembaga membeli formulir pendaftaran kemudian mengisi dan mengembalikan kembali setelah itu harus menunggu beberapa hari lagi untuk mendaftar ulang. Cara yang digunakan oleh lembaga pendidikan bahasa masih belum efektif dilihat dari segi waktu karena calon siswa harus datang berulang kali selama proses pendaftaran. Selain itu cara ini tidak efisien dilihat dari segi keuangan karena calon siswa terus mengeluarkan ongkos transportasi selama proses pendaftaran; (3) promosi - masih kurang karena penekanan promosi hanya dilakukan dengan membagikan brosur-brosur dan hanya menghubungi calon siswa yang ada di daftar booking. Sebagai contoh, calon siswa yang hendak mengikuti pelatihan tetapi kelas untuk materi tersebut tidak dibuka, ia akan dicatat dalam form booking dan akan dihubungi jika kelas tersebut akan dibuka. Namun jika calon siswa tersebut tidak dapat mengikutinya, biasanya ia tidak akan dihubungi kembali. 
Jika ada kelas pelatihan lanjutan, siswa tidak lagi dihubungi kecuali mereka telah memberitahukan sebelumnya bahwa mereka berminat untuk meneruskan kelas pelatihannya.

\section{Alternatif Pemecahan Masalah}

Permasalahan- permasalahan tersebut sangat mengganggu kepuasan baik calon siswa maupun siswa yang kursus di lembaga pendidikan bahasa apabila tidak segera diatasi. Jika tidak teratasi dengan cepat, mereka akan meragukan kemampuan pelayanan dari lembaga pendidikan bahasa dan hal ini akan berdampak tersebarnya pelayanan yang buruk dari lembaga pendidikan bahasa sehingga apabila salah satu sisi berdampak buruk maka akan membuat sisi yang lain juga buruk terutama apabila dihadapkan pada masalah kualitas.

Untuk masalah penjadwalan dan nilai, pihak lembaga pendidikan bahasa akan mengatasinya dengan cara memberikan nomor id bagi setiap siswa yang mengambil kursus di lembaga pendidikan bahasa serta diberikan password guna menjaga terjaminnya kerahasiaan data pribadi mereka, seperti nilai ujian yang mereka dperoleh. Sehingga apabila siswa yang ingin mengetahui nilai dan jadwal mereka, dapat membuka internet untuk melihat jadwal dan nilai mereka tanpa harus mengantri di telepon.

Untuk masalah pendaftaran, lembaga pendidikan bahasa akan membuka pendaftaran secara online untuk mempermudah calon siswa baik dari segi waktu maupun biaya. Akan tetapi pendaftaran langsung masih tetap dibuka. Hal ini dilakukan mengingat apabila tempat tinggal calon siswa dekat dengan lokasi lembaga pendidikan bahasa.

Untuk promosi kelas akan dikirimkan pemberitahuan pembukaan kelas baru melalui e-mail secara terus menerus kepada calon siswa yang telah mengisi form booking. Sedangkan untuk siswa akan dikirimkan email mengenai pembukaan kelas lanjutan dari kelas yang pernah diikuti sebelumnya. Pemberitahuan pembukaan kelas untuk produk-produk lain tetap akan dikirimkan sebagai informasi. Pembukaan kelas baru didasarkan pada permintaan calon siswa dan siswa.

\section{Proses dan Sub Proses Use Case Sistem Web yang Diusulkan}

Sistem proses customer service lembaga pendidikan bahasa yang berjalan memiliki banyak kelemahan sehingga diusulkan sistem yang baru, dan akan digambarkan dalam use case yang diusulkan. Use case yang diusulkan ini berbeda dengan yang ada karena pada sistem yang baru ini menggunakan sebuah sistem web dan didukung oleh konsep CRM. Sistem yang baru ini akan lebih interaksi antara customer service dengan calon siswa maupun siswa melalui hasil analisis atau tampilan yang dihasilkan web aplikasi yang dirancang, sehingga siswa merasa puas dan tetap mempertahankan hubungan yang ada.

\section{PENUTUP}

Dari hasil analisis dan perancangan yang telah dibuat, dapat diambil kesimpulan sebagai berikut: (1) sistem yang berjalan pada customer service lembaga pendidikan bahasa saat ini masih terdapat kekurangan dalam hal berkomunikasi dengan siswa. Siswa mengalami kesulitan mengetahui nilai dan jadwal sehingga harus menanyakannya berulang kali. Selain itu setiap keluhan tidak didokumentasikan, form booking masih bersifat manual dan data siswa disimpan di lembaga pendidikan bahasa pusat; (2) selain dalam mengetahui nilai dan jadwal, calon siswa dan siswa juga mengalami kesulitan dalam hal pendaftaran yang masih dirasa kurang efektif dan efisien; (3) dengan mengusulkan sistem CRM berbasiskan web ini, data-data siswa tersimpan dalam aplikasi yang 
dirancang lembaga pendidikan bahasa sehingga customer service tidak perlu lagi melakukan proses pencarian data secara manual, terutama dalam hal form booking. Aplikasi ini akan mengirimkan email secara langsung kepada siswa apabila kelas yang hendak di-booking akan dibuka. Hal ini sangat membantu customer service jika siswa tidak dapat dihubungi melalui telepon. Selain itu juga setiap keluhan didokumentasikan dalam menu Contact Us. Sistem juga dapat menampilkan nilai dan jadwal kelas sehingga customer service dapat menyampaikan informasi ke siswa dengan efektif.

\section{DAFTAR PUSTAKA}

Greenberg, Paul. (2002). CRM at the Speed of Light: Capturing and Keeping Customers in Internet Real Time ( $2^{\text {nd }}$ Ed.). California: Mc Graw-Hill. 